\title{
ASPEK PEMBENTUK KAWASAN TRANSIT TERHADAP HIBRIDITAS KAWASAN STASIUN SOLOBALAPAN DAN TERMINAL TIRTONADI KOTA SURAKARTA
}

\author{
Atik Prihatiningrum ${ }^{1)}$, Dwi Oktavallyan ${ }^{2)}$ \\ ${ }^{112)}$ Program Studi Arsitektur, Fakultas Teknik UNIB, Jl. W. R. Supratman, \\ Kandang Limun, Bengkulu 38371, Telp. (0736)344087 \\ email: inersia@unib.ac.id
}

\begin{abstract}
Abstrak
Hibriditas dalam konteks tata kota, menghubungkan antara orang dan aktivitas pada titik-titik lebih dari satu kawasan yang memiliki intensitas pergerakan tinggi melalui penegasan jalur dan menghubungkan kawasan-kawasan untuk menciptakan suatu ruang kota yang memiliki kompleditas yang hybrid/ berpadu. Tidak terkecuali pengembangan kawasan kawasan transit yang kompak dan mendukung kegiatan transit, perlu dihubungkan dengan jaringan jalan yang ramah bagi pejalan menuju tujuan lokal berupa tempat komersial, tempat kerja, ruang terbuka, dan perumahan dengan upaya menghibridisasi dua kawasan transit dalam satu pengembangan kawasan transit yang lebih kompleksitas. Hasil penelitian yang didapatkan hibriditas kawasan statisun Solobalapan dan Terminal Tirtonadi saat ini tinggi (skor 5,5) dengan aspek pembentuk kawasan transit yang berdampak secara dominan pada hibriditas kawasan adalah variabel diversitas.
\end{abstract}

Kata kunci: hibriditas, stasiun, terminal, kawasan, transit

\begin{abstract}
Hybridity in the context of urban planning, connecting people and activities at points of more than one region with high-intensity movement through path affirmation and linking areas to create a city space with hybrid / cohesive compilations. No exception is the development of a compact transit area and support for transit activities, it needs to be linked with a pedestrianfriendly road network to local destinations in the form of commercial venues, workplaces, open spaces and housing with the effort to hybridize two transit areas in one more transit area development complexity. The result of research obtained by hybridity of staticun area of Solobalapan and Terminal of Tirtonadi at this time is high (score 5,5) with aspect of forming of transit area that has dominant impact on regional hybridity is diversity variable.
\end{abstract}

Keywords: hybridity, station, terminal, area, transit 


\section{PENDAHULUAN}

Kawasan kota yang terintegrasi dapat diwujudkan dengan membuat pertalian positif antar unsur dalam kawasan yang merespon kebutuhan masyarakat sebagai pelaku, hubungan fungsi yang berkualitas dan diterapkan oleh kombinasi spasial (Trancik, 1986: 219). Interaksi antara bentuk perkotaan, transportasi dan keberlanjutan perkotaan secara konseptual dibentuk dengan unsur-unsur densitas, diversitas, dan desain serta aksesibilitas yang pada akhinya mempengaruhi pola perilaku perjalanan (Kurniawan, 2009:13). Pengembangan di kawasan kota perlu didukung sebuah 'aliran' sebagai pengalaman intens yang terletak di antara kebosanan dan over stimulasi pada pembangunan, terlalu banyak kemudahan gerakan akan menghasilkan kebosanan dan statis (Nan Ellin, 2006:7).

Menurut Munawar 2000 dalam Raniasta, 2013:3 , setiap tata guna lahan atau sistem kegiatan, termasuk pada kawasan berbasis transit di sekitar stasiun, mempunyai jenis kegiatan tertentu yang akan membangkitkan pergerakan (zona bangkitan) dan atau akan menarik pergerakan (zona tarikan) dalam proses pemenuhan kebutuhan. Aktivitas pariwisata, dan perdagangan merupakan faktor penarik bagi masyarakat dan pengunjung dari kota sekitar untuk mengunjungi Surakarta. Keberadaan dua stasiun kereta api besar di pusat kota, yaitu Stasiun Solobalapan dan Stasiun Purwosari menyebabkan moda transportasi kereta api telah menjadi alternatif pilihan bagi masyarakat dari kota-kota satelit (Karanganyar, Boyolali, Sukoharjo, Klaten, Purwodadi) untuk melakukan beraktivitas menuju dan dari kota Surakarta.

Secara geografis, Stasiun Solobalapan dan Terminal Tirtonadi terletak di titik tengah Kota Surakarta, yaitu antara Jalan Ahmad Yani (arteri primer) merupakan jalan utama penghubung antara kabupaten Boyolali dengan Karanganyar dan Jalan Gajah Mada (arteri sekunder) yang menghubungkan jaringan jalan dalam kota. Hal ini menyebabkan Stasiun Solobalapan dan Terminal Tirtonadi menjadi area transit yang dapat menghubungkan pergerakan antara Surakarta sisi Selatan dan Utara sehingga memiliki akses yang strategis dengan berbagai potensi. Potensi yang berada dalam jarak 200 meter sampai $2 \mathrm{~km}$ dari stasiun memiliki pola persebaran mayoritas ke arah selatan, Tenggara, dan Barat daya. Potensi aktivitas di kawasan Stasiun Solobalapan dan Terminal Tirtonadi dapat dikategorikan berupa, aktivitas di pemukiman, perkantoran/industri, fasilitas/ruang publik.

Jacobs, 1961, pp. 143-151 dalam Talen, 2008:9-10 keberagaman artikulasi dan penghubung pada suatu tempat memunculkan keberagaman merespon bentuk fisik dan hubungan pola interaksi yang pada akhirnya membentuk pola aktivitas yang baru dan lebih beragam. Faktor-faktor yang membentuk perkotaan dan mempengaruhi penggunaan transit dalam pengembangan daerah (Translink, 2010:1). Pengembangan kawasan maupun tempat transit itu sendiri dengan harapan penggunaan fasilitas transportasi massal yang lebih efektif dan efisien dapat ditingkatkan. Hal ini untuk mengarahkan sistem transportasi antar moda dapat terpadu dan terintegrasi dengan baik dan mampu memberi kemudahan dan melayani kebutuhan masyarakat yang bergerak dari satu tempat ke tempat lain dengan lebih efisien termasuk keuntungan dari peningkatan nilai guna lahan disekitarnya (Adiwira, 2011: 24). Aspek-aspek pembentuk kawasan yang mempengaruhi penggunaan transit pada kawasan transit terdiri densitas, diversitas, jarak menuju transit, destinasi, desain, manajemen pengelolaan.

Aspek-aspek pembentuk kawaan transit perlu dikaji untuk mengidentifikasi hibriditas kawasan. Dalam proses 
mengintegrasikan kawasan transit maka perlu adanya proses integrasi akan menghasilkan suatu produk yaitu semakin tinggi tingkat kualitas integrasi suatu ruang/kawasan maka akan mengundang aktivitas dan pergerakan yang lebih banyak, secara otomatis akan dapat menimbulkan salah satunya tumbuhnya atraktivitas dan aktivitas yang baru yang dapat mendorong pengembangan ekonomi pada kawasan. Hubungan antara integrasi yang baik ini akan memberikan berbagai pengaruh positif terhadap efek yang ditimbulkan.

Hibridisasi menghubungkan orang dan kegiatan pada titik-titik intensitas disepanjang batas dengan menegaskan jalur penghubung dan menggabungkan kawasankawasan (Ellin, 2006:18). Dalam hal tata kawasan, hibriditas memiliki arti yaitu mencampurkan land use, aktivitas, dan atraktivitas untuk menciptakan suatu ruang kota untuk memiliki kompleksitas yang hybrid/berpadu. Berkembangnya pusat-pusat transit moda transportasi, makin banyaknya ruang-ruang yang dapat digunakan masyarakat secara bebas, fasilitas-fasilitas pendukung suatu kota yang saling melengkapi dan saling mendukung dengan bersinerginya kawasan komersial dan jasa. Penggabungan dalam ruang dan waktu (orang, aktivitas, bisnis dsb) menghasilkan hibriditas baru. Secara tidak langsung aktivitas dan atraktivitas dalam suatu kota sangat berperan besar dalam menentukan daya hidup suatu kota (Ellin, 2006: 17-20).

Rumusan masalah pada penelitian ini adalah mengetahui level hibriditas kawasan Stasiun Solobalapan dan terminal Tirtonadi sebagai kawasan transit. Penelitian ini bertujuan untuk mengetahui dampak aspek pembentuk kawasan transit terhadap hibriditas kawasan Stasiun Solobalapan dan terminal Tirtonadi.

\section{METODE PENELITIAN}

Tahapan pelaksanaan penelitian meliputi Identifikasi kondisi aspek-aspek pembentuk kawasan transit. Tahap selanjutnya adalah identifikasi level hibriditas kawasan.

\section{Identifikasi aspek pembentuk kawasan transit}

Observasi lapangan dilakukan dengan identifikasi aspek pembentuk kawasan transit (densitas, diversitas, destinasi, jarak menuju transit, manajemen pengelolaan). Pengamatan pengguna moda transportasi kereta api dan bus dilakukan pada hari Senin hingga Jumat (mewakili hari kerja penuh), Sabtu, Minggu, dan hari libur. Sistem pembagian waktu amatan dilakukan dengan membuat kategorisasi kegiatan berdasarkan waktu pagi hari (06.00-09.00), siang hari (10.00-15.00), sore hari (16.00-18.00) dan malam hari (19.00-23.00). Data hasil observasi mengenai aspek pembentuk kawasan transit yang ada saat ini dideskripsikan secara kualitatif selanjutnya dianalisis dengan metode peta superimpose pada setiap peta dari masing-masing aspek pembentuk kawasan transit.

\section{Identifikasi dan perhitungan level hibriditas kawasan}

Observasi lapangan dilakukan dengan mengidentifikasi hibriditas kawasan pada kawasan Stasiun Solobalapan dan Terminal Tirtonadi dengan memetakan jenis aktivitas, macam fungsi bangunan, intensitas penggunaan lahan berdasarkan periode waktu, sistem parkir, mengikuti pergerakan pengguna moda transportasi saat berada dalam kawasan penelitian (800 meter), melakukan koding data hasil pemetaan.

Untuk mengetahui aspek apa saja yang berdampak terhadap hibriditas kawasan diperlukan kriteria untuk mengukur bagaimana dampak yang ditimbulkan. Kriteria yang akan digunakan untuk mengukur hibriditas kawasan dilakukan dengan melihat variabel dan parameter yang digunakan untuk menganalisis yang ditinjau dari teori yang digunakan. Pembobotan antar variabel menggunakan metode Analitycal 
Hierarchi Proccess (AHP) didasarkan tingkatan yang pengaruh. Nilai bobot tiap variabel pengaruh tersebut akan dijumlahkan sesuai dengan terpenuhi atau tidaknya parameter. Penjumlahan hasil skoring parameter yang diperoleh menjadi penentuan skoring aspek-aspek pembentuk kawasan transit terhadap hibriditas kawasan. Dilakukan pembahasan dengan memaparkan dan menjelaskan hasil-hasil analisis data yang telah.

Hasil-hasil pembahasan temuan studi selanjutnya akan dibuat kesimpulan dan rekomendasi berupa arahan rekomendasi pengembangan kawasan transit agar dapat meningkatkan hibriditas kawasan Stasiun Solobalapan dan Terminal Tirtonadi menjadi satu kawasan transit baru yang utuh dalam meningkatkan pergerakan masyarakat menggunakan moda transportasi publik di Kota Surakarta

\section{Analisa data}

Berdasarkan tabel dibawah bobot tertinggi hingga terendah pada variabel yang memiliki dampak adalah berikut.

Tabel 1. Bobot Variabel

\begin{tabular}{cccc}
\hline Variabel & bobot & $\begin{array}{c}\text { Dalam } \\
\sum\end{array}$ & $\begin{array}{c}\text { Dalam } \\
\text { Persentase }\end{array}$ \\
\hline Diversity & 8 & 0,2 & $20 \%$ \\
Density & 7 & 0,17 & $17,5 \%$ \\
& & 5 & \\
Demand & 7 & 0,17 & $17,5 \%$ \\
management & & 5 & \\
Destinations & 6 & 0,15 & $15 \%$ \\
$\begin{array}{c}\text { Distance to } \\
\text { transit }\end{array}$ & 6 & 0,15 & $15 \%$ \\
Design & 6 & 0,15 & $15 \%$ \\
$\begin{array}{c}\text { Jumlah total } \\
\text { bobot semua } \\
\text { variabel }\end{array}$ & 40 & 1 & $100 \%$ \\
\hline
\end{tabular}

Pembobotan antar variabel menggunakan metode Analitycal Hierarchi Proccess (AHP) didasarkan tingkatan yang pengaruh. AHP merupakan sistem pembuat keputusan dengan menggunakan model matematis
(Kusuma, 2008). AHP membantu dalam menentukan prioritas dari berbagai variabel dengan melakukan analisa. Adapun kaidah pembobotan menyatakan bahwa:

1. Nilai bobot variabel berkisar antara 0-1 atau antara 0\%-100\% jika menggunakan persentase.

2. Jumlah total bobot semua variabel harus bernilai $1(100 \%)$.

3. Skala pembobotan dengan menggunakan angka netral 0-1.

Untuk menentukan total level hibriditas kawasan secara keseluruhan, maka dari tabel skoring pada tiap kawasan akan dijumlahkan dan dibagi sejumlah kawasan yang diteliti seperti pada gambar berikut.

Tabel 2. Bobot Perhitungan Variabel Dampak

\begin{tabular}{|l|c|c|}
\hline $\begin{array}{l}\text { Variabel } \\
\text { Independent }\end{array}$ & Bobot & $\begin{array}{c}\text { Variabel } \\
\text { Dependent }\end{array}$ \\
\hline Hybridity \\
\hline Diversity & 0,2 & 1 \\
\hline Density & 0,175 & 0 \\
\hline $\begin{array}{l}\text { Demand } \\
\text { managemen }\end{array}$ & 0,175 & 1 \\
\hline Destinations & 0,15 & 1 \\
\hline $\begin{array}{l}\text { Distance to } \\
\text { transit }\end{array}$ & 0,15 & 0 \\
\hline Design & 0,15 & 0 \\
\hline & $\Sigma 1$ & 3 \\
\hline
\end{tabular}

Tabel 3. Perhitungan Level Hibriditas

\begin{tabular}{|l|c|c|}
\hline & Bobot & Hibriditas \\
\hline $\begin{array}{l}\text { Total hibriditas } \\
\text { kawasan A }\end{array}$ & 1 & $\ldots$. \\
\hline $\begin{array}{l}\text { Total hibriditas } \\
\text { kawasan .... }\end{array}$ & 0,5 & $\ldots$. \\
\hline Total & 1,5 & 2,5 \\
\hline $\begin{array}{l}\text { Total hibriditas } \\
\text { keseluruhan }\end{array}$ & $\begin{array}{l}1,5+2,5+ \\
1+3+5+4,5=\ldots . . \\
\text { jumlah kawasan } \\
\text { Hasil= .... }\end{array}$ \\
\hline
\end{tabular}

Nilai level integrasi kawasan secara keseluruhan. a. Integrasi kawasan sangat tinggi $=5,1-6$ b. Integrasi kawasan tinggi $=4,1-5$ c. Integrasi kawasan sedang $=3,1-4$ d. Integrasi kawasan rendah $=2,1-3$ e. Integrasi kawasan sangat Rendah $\quad=1,1-2$ f. Tidak ada Integrasi $=0,1-1$

Email:Inersia@unib.ac.id 


\section{HASIL DAN PEMBAHASAN}

\section{Identifikasi aspek pembentuk kawasan transit}

1. Destinasi

Titik-titik tujuan dan pola angkutan umum lokal yang berada di kawasan Stasiun Solobalapan dan Terminal Tirtonadi dapat dilihat pada Gambar 1.

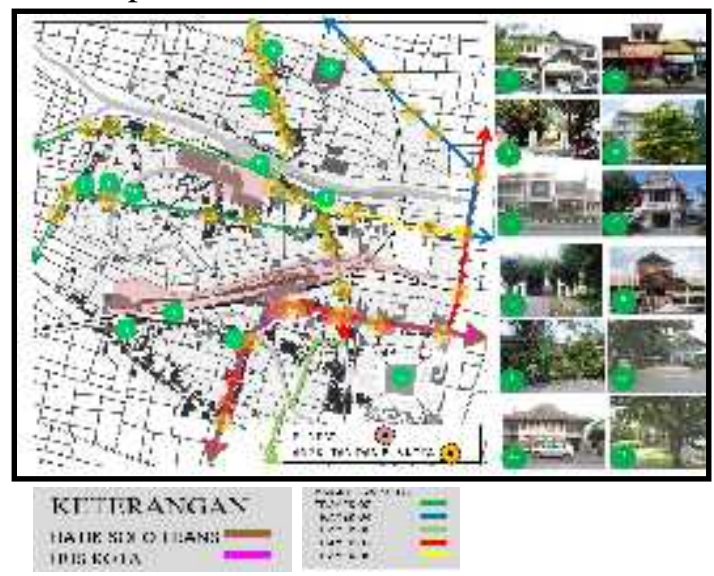

Gambar 1. Titik Tujuan di Kawasan Stasiun Solobalapan dan Terminal Tirtonadi

2. Jarak untuk transit

Jaringan jalan di kawasan Stasiun Solobalapan dan Terminal Tirtonadi ditemukan persimpangan jalan pada ukuran panjang blok \pm 80-326 meter. Beberapa jalan lingkungan memiliki kondisi semakin mengecil dan buntu sehingga tidak bisa terhubung dengan jalan lokal dan jalan kolektor. Jalan alternatif yang banyak digunakan pengguna moda transportasi dari Stasiun Solobalapan ke Terminal Tirtonadi atau sebaliknya adalah jalan kolektor (Jalan Setiabudi).

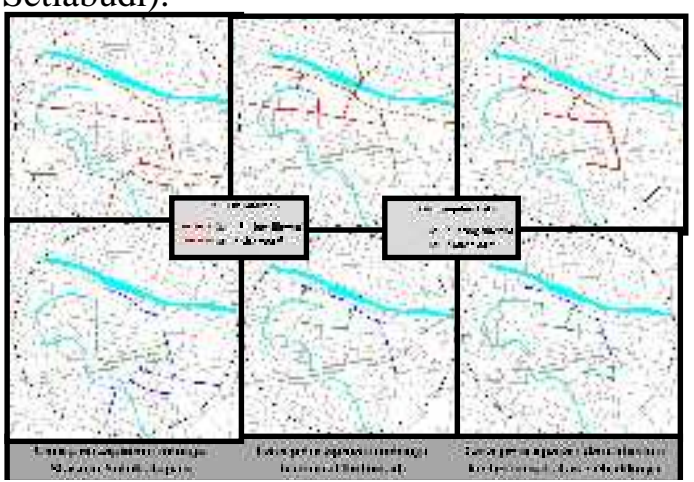

Gambar 2. Jalur yang Sering Digunakan untuk Mencapai Stasiun Solobalapan dan Terminal Tirtonadi

Jurnal Inersia April 2018 Vol.10 No.1

Email:Inersia@unib.ac.id

\section{Densitas}

Kepadatan pemukiman rata-rata di sekitar kawasan Stasiun Solobalapan dan Terminal Tirtonadi mencapai $53,25 \%$ dari total keberagaman fungsi bangunan. Kepadatan bangunan dengan fungsi komersial dan jasa banyak berada di sepanjang koridor jalan (Jalan Setiabudi, jalan RM Said, jalan W. Monginsidi, jalan Gajah mada, jalan Ahmad Yani, jalan Pierre Tendean), di dekat Stasiun Solobalapan dan Terminal Tirtonadi, sekitar perempatan jalan, dekat dengan fasilitas sosial (sekolah, rumah sakit, pasar).

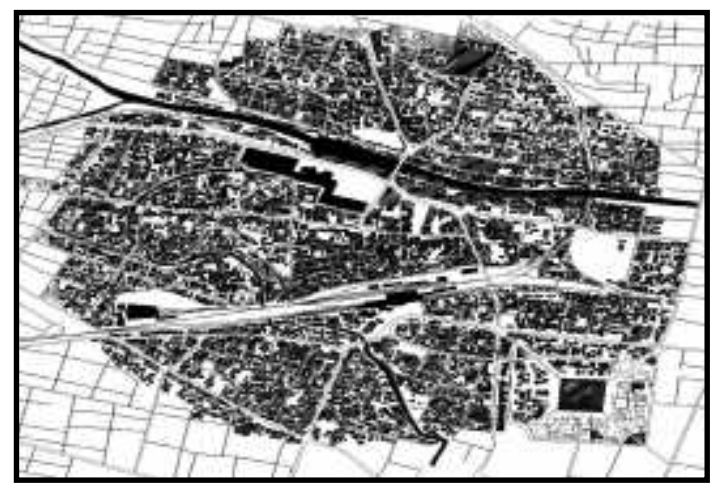

Gambar 3. Kepadatan Bangunan di Kawasan Stasiun Solobalapan dan Terminal Tirtonadi

Tabel 4. Tabel Kepadatan Bangunan per Hektar

\begin{tabular}{|c|c|c|}
\hline $\begin{array}{c}\text { Luas total } \\
\text { area } \\
\text { penelitian } \\
\text { (Ha) }\end{array}$ & $\begin{array}{c}\text { Jumlah } \\
\text { bangunan di } \\
\text { kawasan } \\
\text { Stasiun } \\
\text { Solobalapan }\end{array}$ & $\begin{array}{c}\text { Jumlah } \\
\text { bangunan } \\
\text { di kawasan } \\
\text { Terminal } \\
\text { Tirtonadi }\end{array}$ \\
\hline 251,3 & 7.099 unit & 9.028 unit \\
\hline $\begin{array}{c}\text { Luas per } \\
\text { kawasan }\end{array}$ & $114,5 \mathrm{Ha}$ & $136,8 \mathrm{Ha}$ \\
\hline $\begin{array}{c}\text { Rata-rata } \\
\text { bangunan } \\
\text { per hektar }\end{array}$ & $62 \mathrm{unit} / \mathrm{ha}$ & $66 \mathrm{unit} / \mathrm{ha}$ \\
\hline
\end{tabular}

\section{Diversitas}

Pada area penelitian di radius 800 meter dari Stasiun Solobalapan dan Terminal Tirtonadi, fasilitas-fasilitas yang mudah dan dekat dicapai adalah area pertokoan, pasar, hotel, jasa perjalanan, dan restoran. Keberagaman 
fungsi bangunan berkembang pada jalan arteri sekunder di Selatan Stasiun Solobalapan dan selatan Terminal Tirtonadi. Sedangkan Utara Terminal Tirtonadi didominasi oleh pemukiman. Bentuk massa bangunan yang berukuran sedang hingga besar pada Gambar 4.

Tabel 5. Persentase Fungsi Bangunan dan Luas Terbangun-Tidak Terbangun

\begin{tabular}{|c|c|c|}
\hline Fungsi & \begin{tabular}{|c|} 
Kawasan \\
Stasiun \\
Solobalapan
\end{tabular} & Persentase \\
\hline Pemukiman & $594.853 \mathrm{~m}^{2}$ & $43,4 \%$ \\
\hline Mixed use & $76.705 \mathrm{~m}^{2}$ & $5,6 \%$ \\
\hline $\begin{array}{l}\text { Komersial } \\
\text { dan jasa }\end{array}$ & $182.665 \mathrm{~m}^{2}$ & $13,3 \%$ \\
\hline Perkantoran & $25.907 \mathrm{~m}^{2}$ & $1,8 \%$ \\
\hline $\begin{array}{l}\text { Depo/pabrik/ } \\
\text { gudang }\end{array}$ & $46.382 \mathrm{~m}^{2}$ & $3,3 \%$ \\
\hline PKL & $4.320 \mathrm{~m}^{2}$ & $0,3 \%$ \\
\hline $\begin{array}{l}\text { Fasilitas } \\
\text { transportasi }\end{array}$ & $46.427 \mathrm{~m}^{2}$ & $3,34 \%$ \\
\hline $\begin{array}{l}\text { Fasilitas } \\
\text { umum }\end{array}$ & $69.380 \mathrm{~m}^{2}$ & $5 \%$ \\
\hline Ruang publik & $69.035 \mathrm{~m}^{2}$ & $5 \%$ \\
\hline Pendidikan & $34.030 \mathrm{~m}^{2}$ & $2,4 \%$ \\
\hline Lain-lain & $16.497 \mathrm{~m}^{2}$ & $1.2 \%$ \\
\hline $\begin{array}{l}\text { Total luas } \\
\text { terbangun }\end{array}$ & $\begin{array}{c}1.162893 \\
\mathrm{~m}^{2}\end{array}$ & $85 \%$ \\
\hline $\begin{array}{l}\text { Total luas } \\
\text { lahan tidak } \\
\text { terbangun }\end{array}$ & $205.216 \mathrm{~m}^{2}$ & $15 \%$ \\
\hline $\begin{array}{l}\text { Total } \\
\text { keseluruhan }\end{array}$ & $\begin{array}{c}1.368 .109 \\
\mathrm{~m}^{2}\end{array}$ & $100 \%$ \\
\hline
\end{tabular}

\begin{tabular}{|l|l|l|}
\hline Fungsi & $\begin{array}{l}\text { Kawasan } \\
\text { Terminal } \\
\text { Tirtonadi }\end{array}$ & Persentase \\
\hline Pemukiman & $723.200 \mathrm{~m}^{2}$ & $63,1 \%$ \\
\hline Mixed use & $42.697 \mathrm{~m}^{2}$ & $3,72 \%$ \\
\hline $\begin{array}{l}\text { Komersial } \\
\text { dan jasa }\end{array}$ & $107.592 \mathrm{~m}^{2}$ & $9,39 \%$ \\
\hline Perkantoran & $12.875 \mathrm{~m}^{2}$ & $1,12 \%$ \\
\hline $\begin{array}{l}\text { Depo/pabrik/ } \\
\text { gudang }\end{array}$ & $12.682 \mathrm{~m}^{2}$ & $1.12 \%$ \\
\hline
\end{tabular}

\begin{tabular}{|l|l|l|}
\hline PKL & $4525 \mathrm{~m}^{2}$ & $0,37 \%$ \\
\hline $\begin{array}{l}\text { Fasilitas } \\
\text { transportasi }\end{array}$ & $49.880 \mathrm{~m}^{2}$ & $4,35 \%$ \\
\hline $\begin{array}{l}\text { Fasilitas } \\
\text { umum }\end{array}$ & $38.872 \mathrm{~m}^{2}$ & $3,39 \%$ \\
\hline Ruang publik & $36.812 \mathrm{~m}^{2}$ & $3,21 \%$ \\
\hline Pendidikan & $18.612 \mathrm{~m}^{2}$ & $1,62 \%$ \\
\hline Lain-lain & $54.932 \mathrm{~m}^{2}$ & $4,79 \%$ \\
\hline $\begin{array}{l}\text { Total luas } \\
\text { terbangun }\end{array}$ & $950.979 \mathrm{~m}^{2}$ & $83 \%$ \\
\hline $\begin{array}{l}\text { Total luas } \\
\text { lahan tidak } \\
\text { terbangun }\end{array}$ & $194.778 \mathrm{~m}^{2}$ & $17 \%$ \\
\hline $\begin{array}{l}\text { Total } \\
\text { keseluruhan }\end{array}$ & $\begin{array}{l}1.145 .757 \\
\mathrm{~m}^{2}\end{array}$ & $100 \%$ \\
\hline
\end{tabular}

\section{Desain}

Banyaknya pedestrian yang tersamar dan rusak sehingga pejalan kaki berjalan turun ke jalan yang tidak terlindung dari laju kendaraan. Pejalan kaki juga yang kesulitan untuk menyeberang karena kendaraan tidak menurunkan laju kendaraan sehingga pejalan kaki menunggu untuk menyeberang \pm 5 menit. Pada jalan S.Parman pada ruas perempatan Pro liman sampai perempatan Pasar Papsa Gilingan, pejalan kaki yang kesulitan untuk berjalan dengan nyaman karena pedestrian banyak yang rusak, tidak ada batas lindungan dari kendaraan, ketika siang hari digunakan untuk PKL dan parkir dan ketika malam hari tidak ada penerangan pada pedestrian.

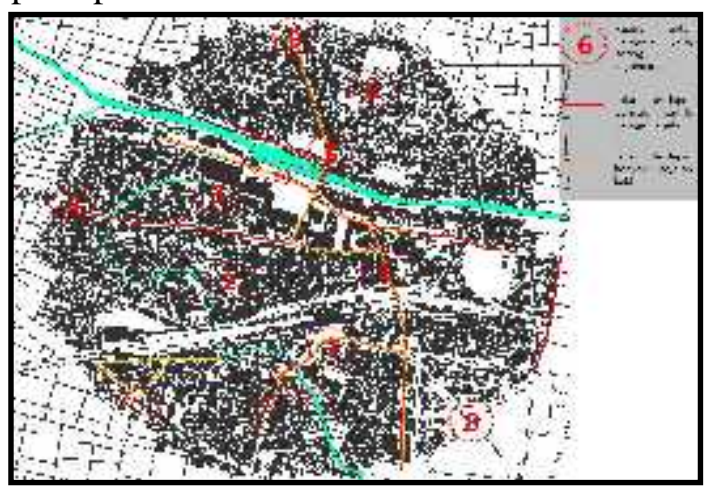

Gambar 4. Peta Jalur Terdapat Banyak Konflik Pengguna Jalan dan Jalur Banyak Pejalan Kaki 


\section{Manajemen pengelolaan}

Titik-titik pengelolaan parkir, parkir yang tersedia di area Stasiun Solobalapan adalah parkir on street dan off street. Sistem parkir on street ini memiliki tarif $\mathrm{Rp} 2.000$ per hari untuk kendaraan roda dua dan $\mathrm{Rp} 5.000$ pada kendaraan roda empat. Untuk jenis kiss and ride di dalam kantong parkir yang di sediakan Stasiun Solobalapan dikenakan tarif $\mathrm{Rp} 2.000$ untuk kendaraan roda dua dan Rp 3.000 pada kendaraan roda empat. Beberapa $20 \%$ dari keseluruhan responden menitipkan kendaraannya di tempat penitipan disekitar stasiun Solobalapan yang aman.

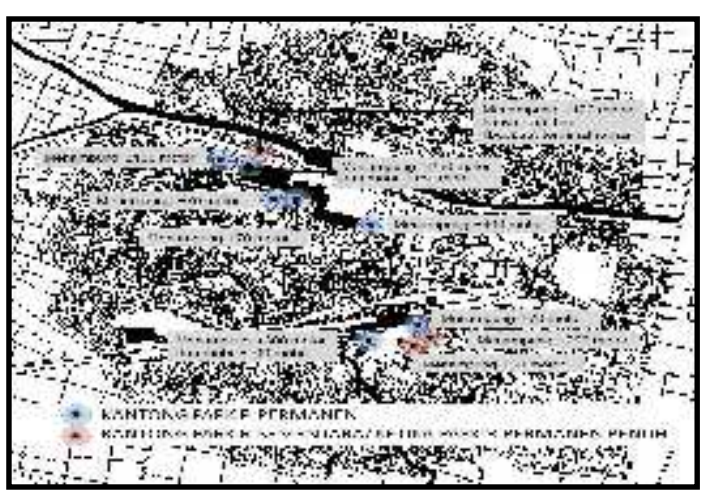

Gambar 5. Persebaran Titik Parkir Off Street pada Kawasan Stasiun dan Terminal

Tabel 6. Analisis Aspek Pembentuk Kawasan Transit

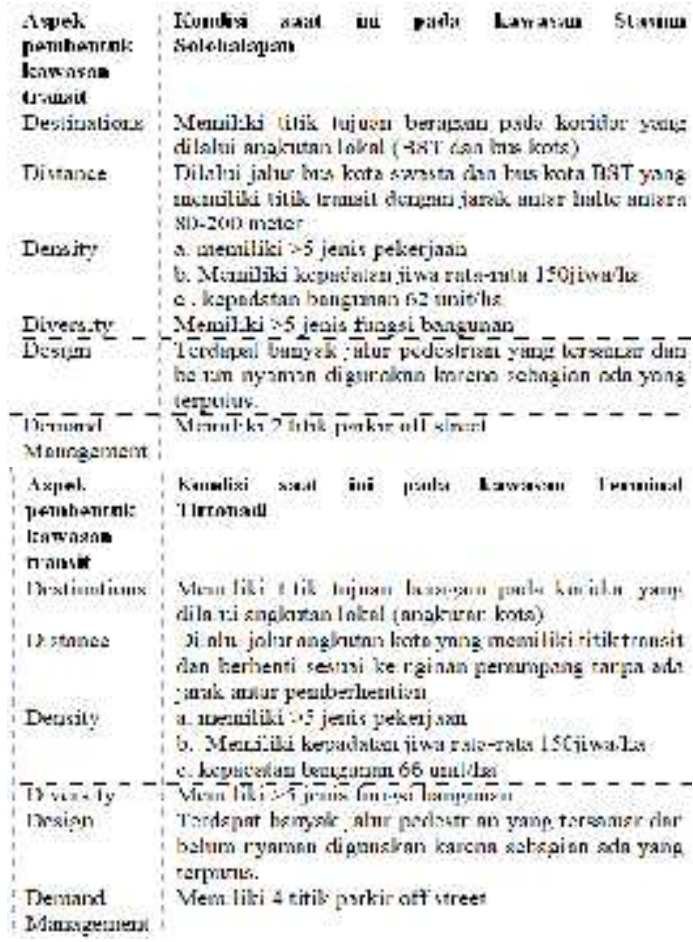

Jurnal Inersia April 2018 Vol.10 No.1
Aktivitas yang muncul pada kawasan Terminal Tirtonadi meliputi aktivitas pergerakan transportasi, menunggu jadwal keberangkatan, menunggu jemputan, aktivitas komersial. Pola aktivitas ditentukan oleh dua faktor, yang pertama adalah propensity (kecenderungan) dan yang kedua adalah opportunity (kesempatan atau peluang) untuk terlibat dalam suatu kegiatan. Faktor kecenderungan tidak hanya dipengaruhi oleh faktor yang membatasi seperti aturan dan karakteristik personal, tetapi juga oleh faktor energi seperti motivasi dan cara berpikir (Chapin, 1974 dalam Ahmad, 2015). Keberadaan atraktivitas seperti PKL, event pasar bekas, parkir on street, yang hanya muncul di malam hari menyebabkan kecenderungan orang untu datang sehingga ruang-ruang di kawasan lebih hidup. Atraktivitas yang terpadu muncul menciptakan pusat-pusat aktivitas baru (Ellin, 2006: 28). Mencampurkan pusat-pusat aktivitas pada pusat transit membentuk keuntungan bagi masing-masing orang dan mengungkapkan identitas kawasan.

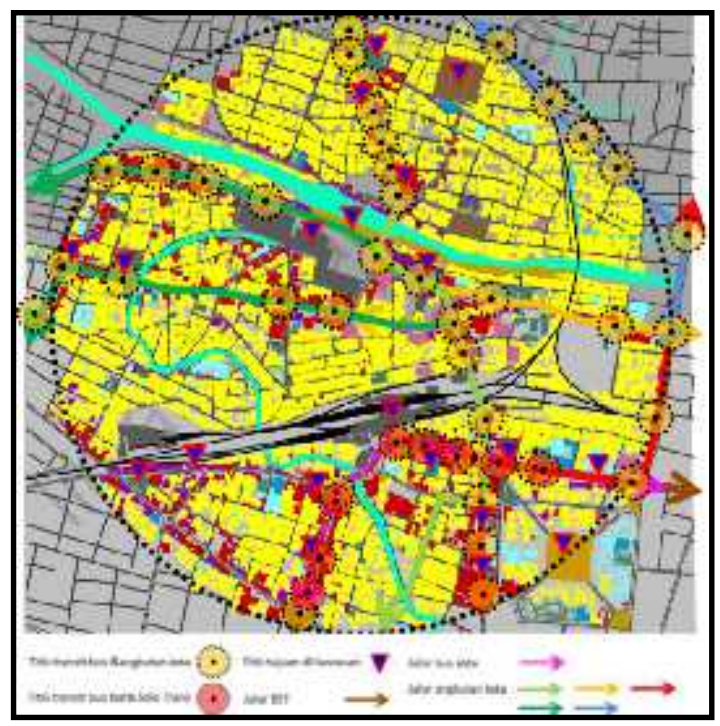


Tabel 7. Aspek Pembentuk Kawasan Transit terhadap Hibriditas Stasiun Solobalapan

\begin{tabular}{|c|c|c|}
\hline $\begin{array}{l}\text { Variabel } \\
\text { pengaruh }\end{array}$ & Kriteria pengaruh & Bobo \\
\hline Density & $\begin{array}{l}\text { Ditemukan fasilitas- } \\
\text { fasilitas pendukung } \\
\text { suatu kota yang } \\
\text { saling mendukung } \\
\text { pada kawasan } \\
\text { berintensitas tinggi } \\
\text { pada orang dan } \\
\text { kegiatan }\end{array}$ & 1 \\
\hline Diversity & $\begin{array}{l}\text { Ditemukan fungsi } \\
\text { bangunan dan } \\
\text { aktivitas yang } \\
\text { beragam di sekitar } \\
\text { kawasan transit. }\end{array}$ & 1 \\
\hline Destinations & $\begin{array}{l}\text { Adanya variasi } \\
\text { tujuan yang beragam } \\
\text { dan memberi daya } \\
\text { tarik visual serta } \\
\text { pengalaman yang } \\
\text { menyenangkan, dan } \\
\text { tidak monoton. }\end{array}$ & 1 \\
\hline $\begin{array}{l}\text { Distance to } \\
\text { transit }\end{array}$ & $\begin{array}{l}\text { jarak antar fasilitas } \\
\text { dan tujuan di sekitar } \\
\text { titik transit } \\
\text { memunculkan } \\
\text { aktivitas baru yang } \\
\text { saling mendukung. }\end{array}$ & 1 \\
\hline Design & $\begin{array}{l}\text { Ditemukan ruang } \\
\text { publik yang } \\
\text { menghubungkan } \\
\text { pergerakan orang dan } \\
\text { kegiatan pada titik- } \\
\text { titik intensitas } \\
\text { dengan menegaskan } \\
\text { jalur penghubung }\end{array}$ & 1 \\
\hline $\begin{array}{c}\text { Demand } \\
\text { management }\end{array}$ & $\begin{array}{l}\text { Adanya sistem } \\
\text { parkir yang mampu } \\
\text { mendukung kegiatan } \\
\text { komersial pada } \\
\text { lokasi penelitian. }\end{array}$ & 1 \\
\hline
\end{tabular}

Tabel 8. Aspek Pembentuk Kawasan Transit terhadap Hibriditas Terminal Tirtonadi

\begin{tabular}{|c|c|c|}
\hline $\begin{array}{l}\text { Variabel } \\
\text { pengaruh }\end{array}$ & Kriteria pengaruh & Bobot \\
\hline Density & $\begin{array}{l}\text { Ditemukan fasilitas- } \\
\text { fasilitas pendukung } \\
\text { suatu kota yang } \\
\text { saling mendukung } \\
\text { pada kawasan } \\
\text { berintensitas tinggi } \\
\text { pada orang dan } \\
\text { kegiatan }\end{array}$ & 1 \\
\hline Diversity & $\begin{array}{l}\text { Ditemukan fungsi } \\
\text { bangunan dan } \\
\text { aktivitas yang } \\
\text { beragam di sekitar } \\
\text { kawasan transit. }\end{array}$ & 1 \\
\hline Destinations & $\begin{array}{l}\text { Adanya variasi } \\
\text { tujuan yang beragam } \\
\text { dan memberi daya } \\
\text { tarik visual serta } \\
\text { pengalaman yang } \\
\text { menyenangkan, dan } \\
\text { tidak monoton. }\end{array}$ & 1 \\
\hline $\begin{array}{l}\text { Distance to } \\
\text { transit }\end{array}$ & $\begin{array}{l}\text { jarak antar fasilitas } \\
\text { dan tujuan di sekitar } \\
\text { titik transit } \\
\text { memunculkan } \\
\text { aktivitas baru yang } \\
\text { salingmendukung. }\end{array}$ & 1 \\
\hline Design & $\begin{array}{l}\text { Ditemukan ruang } \\
\text { publik yang } \\
\text { menghubungkan } \\
\text { pergerakan orang dan } \\
\text { kegiatan pada titik- } \\
\text { titik intensitas } \\
\text { dengan menegaskan } \\
\text { jalur penghubung }\end{array}$ & 0 \\
\hline $\begin{array}{c}\text { Demand } \\
\text { management }\end{array}$ & $\begin{array}{l}\text { Adanya sistem } \\
\text { parkir yang mampu } \\
\text { mendukung kegiatan } \\
\text { komersial pada lokasi } \\
\text { penelitian. }\end{array}$ & 1 \\
\hline
\end{tabular}


Berdasarkan hasil kedua tabel skoring aspek pembentuk kawasan transit Stasiun Solobalapan dan Terminal Tirtonadi maka hasil skoring akhir dari integrasi kedua kawasan secara keseluruhan berupa Tabel 9 berikut ini.

Tabel 9. Skoring Hibriditas Kawasan

\begin{tabular}{|c|c|c|c|}
\hline $\begin{array}{l}\text { Variabel } \\
\text { Independent }\end{array}$ & Bobot & \multicolumn{2}{|c|}{$\begin{array}{c}\text { Variabel Dependent } \\
\text { (Hibriditas) }\end{array}$} \\
\hline & & $\begin{array}{c}\text { Hibriditas } \\
\text { kawasan } \\
\text { Stasiun } \\
\text { Solobalapan }\end{array}$ & $\begin{array}{c}\text { Hibriditas } \\
\text { kawasan } \\
\text { Terminal } \\
\text { Tirtonadi }\end{array}$ \\
\hline Diversitas & 0,2 & 1 & 1 \\
\hline Densitas & 0,175 & 1 & 1 \\
\hline $\begin{array}{c}\text { Manajemen } \\
\text { pengelolaan }\end{array}$ & 0,175 & 1 & 1 \\
\hline Destinasi & 0,15 & 1 & 1 \\
\hline $\begin{array}{c}\text { Jarak ke } \\
\text { transit }\end{array}$ & 0,15 & 1 & 1 \\
\hline Desain & 0,15 & 1 & 0 \\
\hline \multicolumn{2}{|c|}{51} & 6 & 5 \\
\hline Total & \multicolumn{2}{|c|}{5,5} \\
\hline
\end{tabular}

Berkembangnya titik -titik aktivitas dan beragamnya fungsi bangunan pada kawasan Stasiun Solobalapan dan Terminal Tirtonadi dengan hingga pukul 22.00 dan banyaknya ruang-ruang yang dapat digunakan masyarakat secara bebas, fasilitas-fasilitas pendukung suatu kota yang saling melengkapi dan saling mendukung menyebabkan bersinerginya pusat komersial dan jasa pada kawasan Stasiun Solobalapan dan Terminal Tirtonadi. Penggabungan antara aktivitas dan fungsi bangunan menghasilkan hibriditas baru. Secara tidak langsung aktivitas dan atraktivitas dalam kawasan sangat berperan besar dalam menentukan mengurangi kejahatan dan meningkatkan keamanan pada kawasan sekitar Stasiun Solobalapan dan Terminal Tirtonadi di malam hari. Hibriditas kawasan itu sendiri dipengaruhi oleh variabel diversitas karena telah beragamnya fungsi bangunan pada kepadatan bangunan di sepanjang koridor komersial. Pengaruh sistem parkir on street pada jalur yang dilewati oleh angkutan umum lokal di komersial menjadikan kualitas hibriditas semakin kuat. Hanya saja variabel design yang berkaitan dengan jaringan pedestrian belum dapat menfasilitasi pejalan kaki yang dapat meningkatkan hibriditas kawasan lebih kuat lagi.

\section{KESIMPULAN}

1. Besarnya tingkatan hibriditas kawasan saat ini adalah tinggi $(5,5)$ dengan aspek yang berdampak pada hibriditas kawasan secara dominan pada saat ini adalah aspek diversitas. Hibriditas kawasan dipengaruhi oleh diversitas karena beragamnya fungsi bangunan dan aktivitas di pada area komersial dan padat.

2. Aspek-aspek yang memberi dampak terhadap hibriditas kawasan Stasiun Solobalapan dan Terminal Tirtonadi memiliki skor berbeda-beda disebabkan karena faktor pembentuk kawasan transit eksisting yang dimiliki oleh kedua kawasan berbeda sebagai berikut.

a. Kawasan Stasiun Solobalapan memiliki titik tujuan (destinations) yang lebih mudah dicapai karena dilalui oleh bus Batik Solo Trans dan bus kota swasta dibanding kawasan Terminal Tirtonadi yang hanya dilalui oleh angkutan umum.

b. Pengelolaan parkir off street di dalam persil yang letaknya dekat dengan jalan dan mudah dicapai menyebabkan pengguna moda transportasi bus dan kereta api lebih banyak menggunakan kendaraan pribadi menuju Stasiun Solobalapan/Terminal Tirtonadi sehingga hanya sedikit yang ingin menikmati kawasan sekitar Stasiun Solobalapan/Terminal Tirtonadi dengan berjalan kaki. 
DAFTAR PUSTAKA

Adiwira, Fezar. 2011. Reinterpretasi "Transit Place" pada Terminal Penyeberangan Ferry Ujung Surabaya Dengan Tunjauan "Transit Oriented Development". Bandung. Institut Teknologi Bandung. Tesis.

Ahmad, Rimba. 2015. Teori Perilaku Individu dalam Menentukan Aktivitas Perjalanan.

https://ahmadrimba.wordpress.com/201 5/04/30/teori-perilaku-individu-dalammenentukan-aktivitas-perjalanan/. Diakses 12 April 2016

Ellin, Nan. 2006. Integral Urbanism. New York : Routledge.

Kusuma, Palupi Satya. 2008. Identifikasi Kriteria Pemilihan Lahan Rusunami yang Menjadi Daya Tarik Konsumen. Universitas Indonesia
Kurniawan, Iwan. 2009. Penerapan Compact City untuk Pengembangan Kawasan Perkotaan yang Lebih Berkelanjutan. Ringkasan Disertasi. Bandung: Institut Teknologi Bandung.

Raniasta, Yohanes Satyayoga. 2013. Pengembangan Kawasan Stasiun Tugu Yogyakarta Berbasis Transit dengan Pendekatan Aksesibilitas. Universitas Gadjah Mada.Tesis.

Talen, Emily. 2008. Design for Diversity. Exploring Socially Mixed Neighborhoods. Oxford: Elsevier.

Trancik, Roger. 1986. Finding Lost Space. New York: John Wiley \& Sons inc. Pp.219-220

Translink., 2010. Transit-Oriented Communities. A Literature Review on the Relationship Between the Built Environment and Transit Ridership. Reconnecting America: Translink. 